Research Article

\title{
A Study of the Anchorage Body Fracture Evolution and the Energy Dissipation Rule: Comparison between Tensioned Rock Bolts and Torqued Rock Bolts
}

\author{
Bowen Wu $\mathbb{D}^{1,2}$ Xiangyu Wang $\mathbb{D}^{1,}$, ${ }^{1,2}$ Jianbiao Bai $\mathbb{D}^{2},{ }^{2}$ Shuaigang Liu $\left(\mathbb{D},{ }^{1,2}\right.$ \\ Guanghui Wang, ${ }^{1,2}$ and Guanjun $\mathrm{Li}^{1,2}$ \\ ${ }^{1}$ School of Mines, China University of Mining \& Technology, Xuzhou 221116, China \\ ${ }^{2}$ State Key Laboratory of Coal Resources and Safe Mining, Xuzhou 221116, China \\ Correspondence should be addressed to Xiangyu Wang; wangxiangyu_cumt@163.com
}

Received 12 January 2021; Revised 19 January 2021; Accepted 4 February 2021; Published 15 February 2021

Academic Editor: Jian Ji

Copyright (c) 2021 Bowen Wu et al. This is an open access article distributed under the Creative Commons Attribution License, which permits unrestricted use, distribution, and reproduction in any medium, provided the original work is properly cited.

\begin{abstract}
Rock bolt support is an effective technique for controlling surrounding rock of deep roadway. The stability of the anchorage body composed of rock bolts and surrounding rock mass is the core in keeping the stability of roadways. In this paper, the UDEC Trigon model was used in simulating uniaxial compressive test on the anchorage body under different pretension loads. The energy equilibrium criterion of the anchorage body under the uniaxial compressive state was proposed. Furthermore, the fracture evolution and the energy dissipation during the failure process of the anchorage body were analyzed. Results showed that before the peak strength, the external work was stored in the anchorage body in the form of the elastic strain energy $\left(U^{e}\right)$. After the peak, energy dissipated through three ways, including the fracture developing friction $\left(W_{f}\right)$, plastic deformation $\left(W_{p}\right)$, and acoustic emission $\left(U^{r}\right)$. Based on the simulation results, the high pretensioned rock bolts can eliminate the continuous tensile fractures in the anchorage body, decreasing the damaging extent of the anchorage body and the energy that was consumed by the following two main approaches: fracture developing friction $\left(W_{f}\right)$ and plastic deformation $\left(W_{p}\right)$. Moreover, the surplus of the elastic strain energy $\left(U^{e}\right)$ and the strength of the anchorage body can be improved. The pretension load had a positive relationship with elastic strain energy and a negative relationship with the anchorage body damage degree. Based on the above research, the transport roadway of the working face 6208 in the Wangzhuang Coal Mine selected tensile rock bolts to establish the high-performance anchorage body. The monitoring data showed that this reinforcement method effectively managed the serious deformation issue of the roadway surrounding the rock masses.
\end{abstract}

\section{Introduction}

In recent years, the depth of coal mining has been increasing at an annual rate of 6-10 $\mathrm{m}$ [1]. Under the superposition of the high in situ stress and the strong mining stress in the surrounding rock of the deep roadway, the surrounding rock of the roadway is prone to unsteady failure characteristics, and it may cause disasters in severe cases. The stability control of the surrounding rock of the roadway is one of the major problems to be solved in deep mining [2-4]. Massive engineering practices demonstrated that rock bolt reinforcement can effectively improve the stability of the surrounding rock mass [5-7]. Therefore, the rock bolt reinforcement technology, regarded as an active reinforcement method, has been widely implemented in mining engineering in China. The anchorage body composed of rock bolts and the surrounding rock mass is the core to measure the stability of the roadway surrounding the rock mass. This is because it can control the volume expanding, deformation, and failure of the rock mass in the anchorage area [8-10]. To date, researchers have conducted substantial research regarding the anchorage body [11-13]. Wei and Gou [14] used the numerical simulation method to study the parameters of the anchorage body under the effect of pretensioned rock bolts and the instability condition of the anchorage body under in situ stresses. Results suggested that in the in situ stress environment, influence of the surrounding 
rock mass strength around the roadway, the rock bolt pretension load, the lateral pressure coefficient of the in situ stress, the depth of the cover, the rock bolt interval, and the rock bolt spacing decreased successively. Wang et al. [15] deduced the theoretical equation of the shear strength for the anchorage body before and after grouting. The analysis illustrated that after grouting and reinforcing, with the greater mechanical parameters of the surrounding rock mass (elastic modulus, cohesion, internal friction angle and dilation angle), shear strength of the anchorage body increased significantly. Wu et al. [16] analyzed the acting response of the anchored surrounding rock mass under the dynamic loading impact. It was found that under the dynamic loading impact, the anchored surrounding rock mass of the roadway was subjected to repeated compression and tension. This resulted in the development of joints and fractures, which in turn led to the failure of the anchorage system. Wang et al. [17] investigated the effect of the anchoring length of the rock bolts and the pretension force on the stability of the anchorage body. It indicated that increasing the pretension force more effectively control the surrounding rock masses. When the anchorage length of the rock bolt was constant, the effective compressive stress area of the surrounding rock mass in the nonanchored section increased with the pretension force. Liu et al. [18] proposed the concept of the coordinated effect of the anchorage system. They believed that high pretension force was the major factor to develop the effect of the anchorage system.

It can be found that the research on the anchorage body conducted by predecessors mainly focused on the anchorage technology, the anchorage material, the coordinated effect, the stress transfer rule, and the dynamic loading character. As for the theoretical analysis, the traditional elastic-plastic mechanics was usually used. The stress-strain relationship was used to depict the mechanical acting character in the deformational failure process of the anchorage body. Based on this, the strength theory was established. However, the theory cannot truly reflect the deformational failure rule of the anchorage body.

In fact, the anchorage body in underground engineering is a highly nonlinear, complicated system. Furthermore, it is in the dynamic irreversible evolution period. Therefore, the deformational failure process of the anchorage body is the complicated conversion process of the energy, which is a status instability phenomenon driven by energy. The core of the damaging evolution of the anchorage body is the process of energy dissipation and release. The evolution rule of energy is the core expression of the deformational failure for the anchorage body [19-21]. Using the perspective of energy to analyze and explain the mechanical responding characters of the deformational failure in the anchorage body is an effective method.

Moreover, researchers have already used theoretical analysis and laboratory experiments to conduct research on the energy dissipating and releasing mechanism of the rock failure [22-25]. Meng et al. [26] analyzed the acoustic emission and the energy evolution character of the rock samples under the uniaxial cyclic unloading compression condition. The results showed that the energy evolution of rock masses had a close relationship with the axial loading stress, rather than the axial displacement rate. Before the axial load reached its peak strength, the energy accumulation accounted for the leading role. After that, the energy dissipation accounted for the leading role. The input energy led to generation of microfractures in the rock mass and irreversible development. The releasing of the elastic energy resulted in the instability of the rock mass. Moreover, this induced damage to rock mass. Dong et al. [27] studied the energy evolution process of the rock masses in the mining process. According to the variation tendency of energy, the dissipating process was divided into the initiating stage, the stable increasing stage, the dramatic increasing stage, and the stable stage. However, limited research has been conducted on studying the energy dissipation in the failure process of the anchorage body via the numerical simulation method. Previous studies found that the fracture development was the internal reason leading to the instability of the anchorage body [28, 29]. However, the pretension force was the primary external influencing parameter in affecting the stability of the anchorage body [12]. Therefore, in this study, the UDEC Trigon method was used to carry out the Uniaxial Compressive Strength (UCS) test on the anchorage body under various pretension forces. The energy evolution and the fracture development of the anchorage body with different pretension forces were monitored. The relationship between the pretension force, the fracture development of the anchorage body, and the energy in the anchorage body was studied. The failure character of the anchorage body was analyzed from the perspective of energy. It is expected that the research results can be more representative of the deformational failure rule of the anchorage body.

\section{Energy Balance and Components}

Since the 1960s, scholars have conducted a significant body of research on the theory of energy equilibrium in rock mechanics [30-34]. From the initial rough studying of the energy variation in the underground mining process, these energy concepts gradually developed to a detailed study of the energy evolution of the rock masses under the conditions of the different buried depth, the loading and the unloading method, and the confining pressure. Based on summarizing the previous scholars' work, this study combined the simulation condition to determine the energy equilibrium criteria.

During the UCS process, the applied work by the external force was expressed with $W$. Due to the elastic deformation of the anchorage body, certain forces were stored in the internal area of the anchorage body in the form of elastic strain energy. The energy of this section was expressed with $U^{e}$. The difference between the applied work by the model boundary and the elastic strain energy was the dissipating energy $\left(U^{d}\right)$. Therefore, the total input energy $(W)$ induced by the applied work of the external forces can be expressed with

$$
W=U^{d}+U^{e}
$$

Energy was mainly dissipated through three approaches. The first approach was generating, developing, closing, and fracture friction in the rock masses. The dissipated energy by 
them was $W_{f}$. The second approach was the plastic deformation of the rock masses $\left(W_{p}\right)$. When the rock block generated irreversible deformation, energy was dissipated through the plastic work. The residual section was commonly released through acoustic emission, which can be expressed with $U^{r}$. Therefore, the dissipated energy $U^{d}$ can also be defined as

$$
U^{d}=W_{f}+W_{p}+U^{r}
$$

In UDEC, the increment variation of this energy was determined and accumulated in each timestep [35]. Combining equations (1) and (2), in this study, the energy equilibrium equation that was used to calculate the energy releasing can be written as

$$
W=W_{f}+W_{p}+U^{r}+U^{e} .
$$

Then, this energy equilibrium concept was used to discuss the energy dissipation of the complicated anchorage body.

\section{Parameter Calibration}

3.1. The UDEC Trigon Approach. The UDEC Trigon model was proposed by Gao et al. [36] to simulate brittle fracture of the rock. In this model, a rock is represented by an assembly of triangular blocks bonded together via their grain contacts. Each block is made elastic by dividing them into triangular finite difference zones. Hence, the block does not fail by plastic yielding. Failure can only occur along the contacts in shear or tension, depending on the stress state and the properties of the contact surface [35]. In the direction normal to a contact, the stress-displacement relation is assumed to be linear and governed by the stiffness $k_{\mathrm{n}}$ :

$$
\Delta \sigma_{n}=-k_{n} \Delta u_{n}
$$

where $\triangle \sigma_{n}$ is the effective normal stress increment and $\Delta u_{n}$ is the normal displacement increments. A limiting tensile strength $(T)$ is assumed for the contact. If this value is exceeded, then $\sigma_{n}=0$.

Along the shear direction, the response is governed by constant shear stiffness. The shear stress $\left(\tau_{s}\right)$ is determined by a combination of contact properties: cohesion $(c)$ and friction $(\varphi)$.

$$
\left|\tau_{s}\right| \leq c+\sigma_{n} \tan \varphi=\tau_{\max } .
$$

Then,

$$
\tau_{s=}-k_{s} u_{s}^{e} .
$$

However, if $\left|\tau_{s}\right| \geq \tau_{\max }$, then,

$$
\tau_{s}=\operatorname{sign}\left(\Delta u_{s}^{e}\right) \tau_{\max } .
$$

where $\Delta u_{s}^{e}$ is the elastic component of the incremental shear displacement and $\Delta_{u}^{s}$ is the total incremental shear displacement.

The proposed modeling approach has been implemented within UDEC [35].
3.2. Mechanical Parameters of the Anchorage Body. As the UDEC Trigon model defines the block as the elastic material, plastic failure cannot be generated. However, in the anchorage body, failure is elastoplastic. Therefore, to accurately simulate the physical and mechanical characters and the energy dissipating rule after the anchorage body fails, based on the UDEC Trigon block, this study used the strainsoftening model for the block. The strain-softening model is based on the UDEC Mohr-Coulomb model with nonassociated shear and associated tension flow rules.

The intact properties of the coal are listed in Table 1. These properties were obtained through laboratory tests and were provided by the Wangzhuang Coal Mine. The RQD values of the coal masses were evaluated from borehole televiewer images.

The rock mass elastic modulus was calculated using the relationship between RQD and the elastic modulus ratio [37], as shown in equation (7), where $E_{m}$ is the elastic modulus of the rock mass and $E_{r}$ is the elastic modulus of the rock sample.

$$
\frac{E_{m}}{E_{r}}=10^{0.0186 R Q D-1.91}
$$

The rock mass strength was calculated using the relation between the UCS ratio $\sigma_{c m} / \sigma_{c}$ and the deformation modulus ratio $E_{m} / E_{r}$ [38]. The value of $q$ is 0.63 [39]:

$$
\frac{\sigma_{c m}}{\sigma_{c}}=\left(\frac{E_{m}}{E_{r}}\right)^{q} .
$$

To represent the coal by using an assembly of triangular blocks, the properties of the blocks and contacts were calibrated against the coal properties listed in Table 2. This was achieved by simulating UCS tests in a numerical model created using the Trigon logic. The size of the rock sample is $2 \mathrm{~m}$ (in width) $\times 4 \mathrm{~m}$ (in height) [38] (Figure 1). The bottom of the numerical model was fixed and a displacement rate of $0.02 \mathrm{~m} / \mathrm{s}$ was applied at the top. The calibrated properties of the UDEC model are illustrated in Table 3.

The UCS and elastic modulus data derived by numerical simulation are consistent with laboratory tests (within an error of $7 \%$ ). Hence, the reasonable availability of the micromechanical parameters of the coal mass and the rock mass was verified.

3.3. Rock Bolt Parameters. The "cable" structural element in UDEC was adopted to simulate the rock bolts. The parameters of the "cable" element are presented in Table 4. A detailed description of the support elements in UDEC is provided by the Itasca Consulting Group Inc. For resingrouted rock bolts, two key properties governing the anchor characteristics are the stiffness $\left(K_{\text {bond }}\right)$ and the cohesive strength $\left(S_{\text {bond }}\right)$ of the grout. A practical estimation of $K_{\text {bond }}$ was provided in the UDEC manual [36] as

$$
K_{\text {bond }} \cong \frac{2 \pi G}{10 \ln (1+2 t / D)},
$$


TABLE 1: Intact rock properties and scaled rock mass properties of coal from the Wangzhuang Coal Mine.

\begin{tabular}{lcccccc}
\hline \multirow{2}{*}{ Coal measures } & \multicolumn{2}{c}{ Intact rock } & \multicolumn{2}{c}{ RQD $(\%)$} & \multicolumn{3}{c}{ Rock mass } \\
& $E_{r}(\mathrm{GPa})$ & $\sigma_{r}(\mathrm{MPa})$ & & $E_{m}(\mathrm{GPa})$ & $\sigma_{c m}(\mathrm{MPa})$ & $\sigma_{t m}(\mathrm{MPa})$ \\
\hline Coal & 2.6 & 10.8 & 75 & 0.79 & 5.1 & 0.51 \\
\hline
\end{tabular}

TABLE 2: Calibrated mechanical parameters of blocks and joints of the coal.

\begin{tabular}{|c|c|c|c|c|c|}
\hline & Density $\left(\mathrm{kg} / \mathrm{m}^{3}\right)$ & $\begin{array}{l}\text { Young's modulus } \\
(\mathrm{GPa})\end{array}$ & $\begin{array}{l}\text { Cohesion } \\
(\mathrm{MPa}) \\
1.6(\varepsilon=0)\end{array}$ & $\begin{array}{l}\text { Friction } \\
\quad\left({ }^{\circ}\right)\end{array}$ & $\begin{array}{l}\text { Tensile strength } \\
(\mathrm{MPa})\end{array}$ \\
\hline Block & 1400 & 0.79 & $\begin{array}{l}1.1(\varepsilon=0.04) \\
0.6(\varepsilon=0.15)\end{array}$ & 27 & 0.9 \\
\hline Joint & $\begin{array}{c}\text { Normal stiffness } \\
(\mathrm{GPa} / \mathrm{m}) \\
113\end{array}$ & $\begin{array}{l}\text { Tangential stiffness } \\
\qquad(\mathrm{GPa} / \mathrm{m}) \\
45.2\end{array}$ & $\begin{array}{c}\text { Cohesion } \\
\text { (MPa) } \\
1.3\end{array}$ & $\begin{array}{l}\text { Friction } \\
\left({ }^{\circ}\right) \\
18\end{array}$ & $\begin{array}{c}\text { Tensile strength } \\
\text { (MPa) } \\
0.4\end{array}$ \\
\hline
\end{tabular}

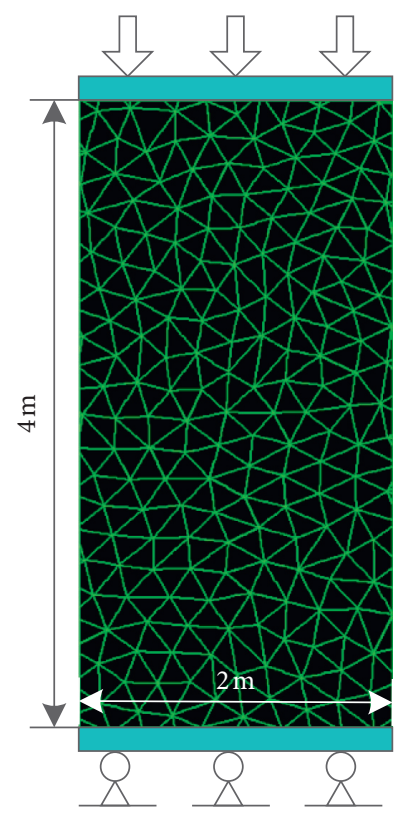

(a)

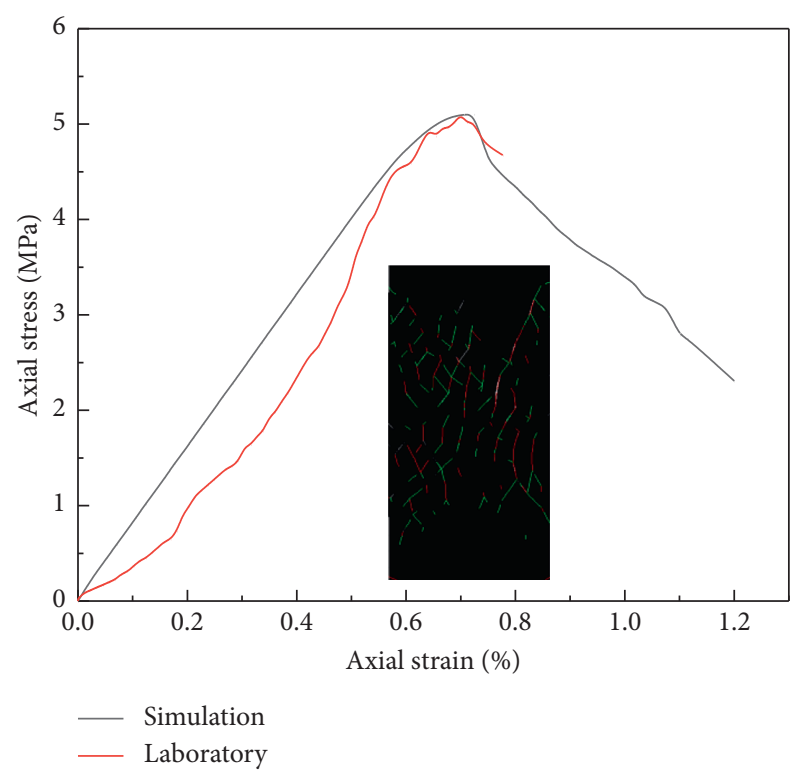

(b)

FIgURE 1: Results of UCS testing: (a) numerical simulation of uniaxial compression and (b) stress-strain curve of coal.

TABLE 3: Calibrated microproperties in the UDEC Trigon model to represent the coal.

\begin{tabular}{|c|c|c|c|c|c|c|}
\hline \multirow{2}{*}{ Coal measures } & \multicolumn{3}{|c|}{ Young's modulus (GPa) } & \multicolumn{3}{|c|}{ Compressive strength $(\mathrm{MPa})$} \\
\hline & Target & Calibrated & Error (\%) & Target & Calibrated & Error (\%) \\
\hline Coal & 0.79 & 0.73 & 7 & 5.1 & 5.1 & 0 \\
\hline
\end{tabular}

TABle 4: Properties of support elements in UDEC.

\begin{tabular}{lc}
\hline Contact properties & Value \\
\hline Elastic modulus $(\mathrm{GPa})$ & 200 \\
Tensile yield strength $(\mathrm{kN})$ & 390 \\
Stiffness of the grout $(\mathrm{N} / \mathrm{m} / \mathrm{m})$ & $2 \mathrm{e} 9$ \\
Cohesive capacity of the grout $(\mathrm{N} / \mathrm{m})$ & $4 \mathrm{e} 5$ \\
\hline
\end{tabular}


where $G$ : the grout shear modulus; $D$ : the bolt diameter, and $t$ : the annulus thickness. Zipf [40] provided practical values of $S_{\text {bond }}$ for simulating resin-grouted rock bolts installed in varying Coal Measures. A value of $400 \mathrm{kN} / \mathrm{m}$ of $S_{\text {bond }}$ was adopted in this study.

\section{Fracture Evolution and Energy Dissipating Rule of the Anchorage Body}

4.1. Simulation Method and the Model Building. According to the physical and the mechanical characters of the in situ anchorage body, the UDEC Trigon simulation method was used to conduct research on the fracture evolution and energy dissipating rule of the anchorage body (Figure 2) The supporting resistance of the rock bolts to the surrounding rock is far from the in situ stress, so that the influence of the rock bolt supporting effect on the surrounding rock cannot be effectively displayed, and hence, the effect of in situ stress is ignored in the simulation. In the model, for the zone and the interface, the strain-softening model and the coulomb slip model were used, respectively. The model was a rectangle with the width-height ratio of 1 : 2. The dimension was $2 \mathrm{~m}$ in width and $4 \mathrm{~m}$ in height. At the middle of the model bottom boundary, a rock bolt with a length of $2.4 \mathrm{~m}$ was installed. At the top of the model, a loading velocity of $0.02 \mathrm{~m} / \mathrm{s}$ was applied. The bottom boundary of the model was fixed. During the loading process of the model, the FISH function was used to monitor the stress in the anchorage body, the quantity of shearing fractures, the length of shearing fractures, the quantity of tensile fractures, and the length of tensile fractures. The energy module in UDEC was used to monitor parameters such as the applied work by the boundary forces, the applied work by friction, and the applied work by plasticity. Based on whether it was anchored and the difference of the rock bolt pretension forces, three simulation schemes were established: (1) no rock bolt; (2) rock bolts with low pretension forces; and (3) rock bolts with high pretension forces. Table 5 shows the specific parameters of each scheme. In the field, the pretensioned torque that was applied on rock bolts commonly ranged from 300 to $400 \mathrm{Nm}$. The corresponding pretension forces ranged from $40 \mathrm{kN}$ to $50 \mathrm{kN}$ [41]. Therefore, in this study, in the simulation scheme, the low pretension force was $40 \mathrm{kN}$.

For rock bolts, the other parameters were equal except that the pretension force was different.

Attention should be paid that when energy was monitored, the command of "SET energy on" should be used to activate the energy monitoring module. In addition, the mass-scaling option was shut down. Because in this study, the nonsticky boundary was used and the dynamic calculating analysis was not involved, the damping was set as "Damping auto." The modeling processes were described as: (a) establishing the model and applying the calibrated parameters on the model; (b) according to the simulated scheme, conducting loading simulation on the anchorage body; and (c) finally, according to the monitored data, analyzing the energy dissipating rule of the anchorage body. Figure 2 shows the schematic diagram of the model.
4.2. Deformational Failure Character and Energy Dissipating Rule of the Anchorage Body. Figure 3 shows that when there was no rock bolt, there were massive continuous fractures distributed in the anchorage body. In particular, at the upper right of the anchorage body, there were coalescence of shear and tensile fractures. In the anchorage body with low pretensioned rock bolt installed, fractures developed in the body were lower than that shown in Figure 3(a), indicating that pretension has an impact on the fracture distribution. Thereby, the number of cracks was also reduced compared to that of no rock bolt. In the anchorage body with high pretensioned rock bolts installed, most fractures were shear and a substantial decrease in the total fractures can be observed. It is noted that there were only a small number of discontinuous tensile fractures at the corner of the top and the bottom. Therefore, high pretensioned rock bolts can effectively reduce the quantity of the continuous tensile fractures in the anchorage body. Also, the condition of the anchorage body can be improved, which was beneficial for ensuring the integrity and stabilization of the anchorage body.

Figure 4 shows the processing results of the monitored data. These nine figures were classified into groups along the vertical direction according to the simulation scheme. From the left to the right, they were anchorage body without the rock bolt, anchorage body with low pretensioned rock bolts, and anchorage body with high pretensioned rock bolts. Along the horizontal direction, they were classified into groups, according to the anchorage body strength, fracture developing, and energy variation. The damaging extent of the anchorage body was determined by the ratio of damage length of the contact surface (including both shear cracks and tensile cracks) to the total length [37]. From the top to bottom, they were stress-strain curves, fracture-strain curves, and energy-strain curves. The fracture-strain curves include shearing fractures, tensile fractures, total damaging extent, shearing damaging extent, and tensile damaging extent. The energy-strain curves include the applied work by the boundary, the elastic strain energy, applied work by friction, applied work by plasticity, and released energy.

First, analysis was conducted on Figure 4 along the vertical direction. According to the tendency of the fracture curve and the energy curve, and the relationship between them and the stress curve, the whole failure process of the anchorage body was divided into three stages: fracture initiating stage (Phase I), rapid developing stage of fractures (Phase II), and the post-peak stage (Phase III).

The fracture initiating stage (Phase I) started from zero to around $80 \%$ of the peak strength. In this stage, the fractures and the damaging extent were at a relatively low level. The anchorage body was in the elastic strain stage. The externally imported energy was almost all transferred to the elastic strain energy, which was stored in the anchorage body. In this stage, there was very minor energy dissipation induced by the anchorage body failure.

The rapid developing stage of fractures (Phase II) started from around $80 \%$ of the peak strength to the peak strength. In this stage, the shearing fractures developed rapidly, leading to the damage of the anchorage body. However, the tensile fractures were still at a relatively low level. Therefore, 


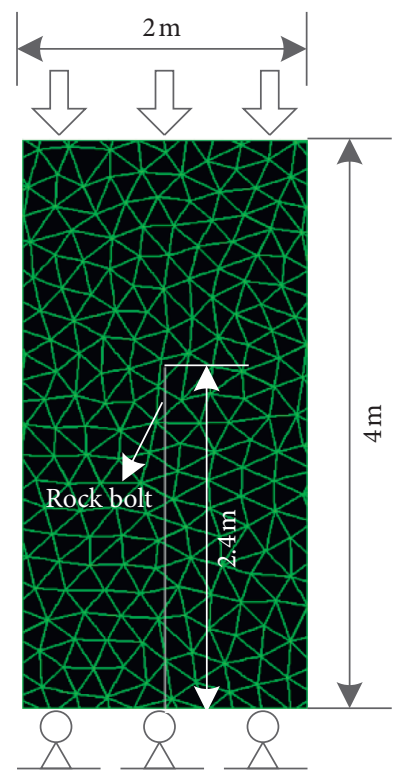

FIgURE 2: Model overview and dimensions.

TABLE 5: Numerical simulation scheme.

\begin{tabular}{lccc}
\hline & Whether there are rock bolts & Rock bolt pretension force & Displacement rate \\
\hline Scheme I & No & - & $0.02 \mathrm{~m} / \mathrm{s}$ \\
Scheme II & Yes (torqued rock bolts) & Low $(40 \mathrm{kN})$ & $0.02 \mathrm{~m} / \mathrm{s}$ \\
Scheme III & Yes (tensile rock bolts) & High $(90 \mathrm{kN})$ & $0.02 \mathrm{~m} / \mathrm{s}$ \\
\hline
\end{tabular}

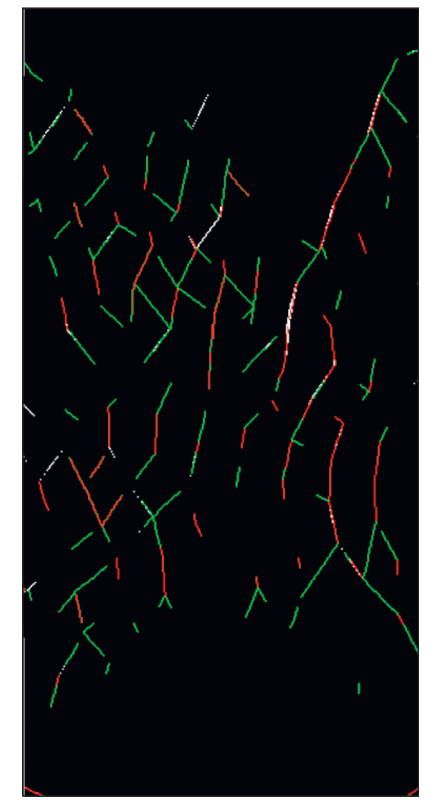

Tensile cracks
Shear cracks

(a)

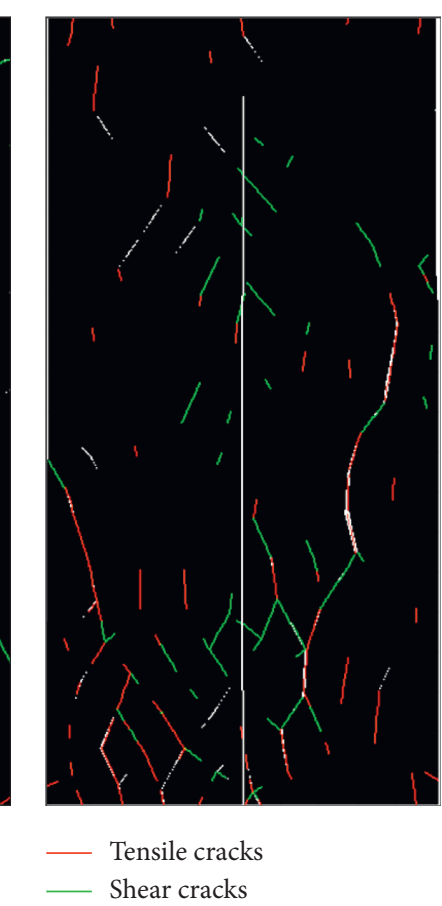

(b)

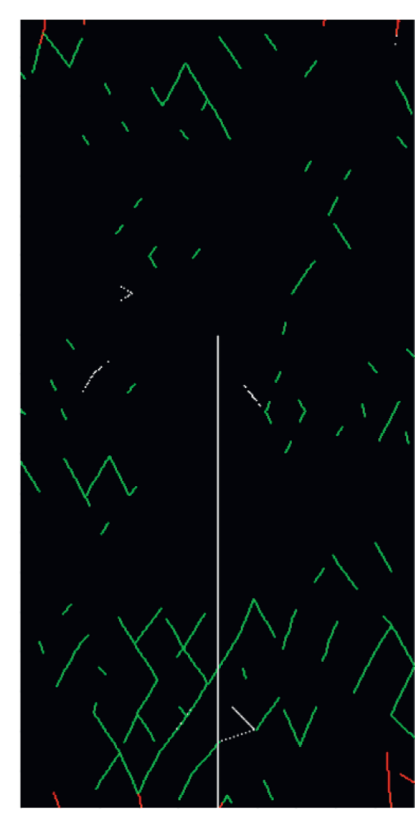

_ Tensile cracks

Shear cracks

FIGURE 3: Failure of anchorage body: (a) no rock bolt; (b) a rock bolt with low pretension; (c) a rock bolt with high pretension. 
in this stage, the developing and propagation of shearing fractures were the principal factors leading to the failure of the anchorage body. In this stage, a small amount of energy was dissipated through applying work with fracture friction and applying work with plastic deformation. However, more energy was still stored in the anchorage body in the form of the elastic strain energy. Furthermore, around the peak strength, it reached the peak of the elastic strain energy.

The post-peak stage (Phase III) indicated the section that was after the peak. In this stage, the development of the shearing fractures in the anchorage body became stable. However, at this time, the tensile fractures in the low level in previous two stages showed increasing tendency in this stage. Not only the quantity but also the extent of damage resulted by tension increased. In this stage, a quantity of energy was dissipated through applying work via fracture friction and applying work via plastic deformation. The energy released by acoustic emission also increased rapidly. The anchorage body gradually entered the plastic strain. The internal elastic strain energy decreased from the peak. All dissipated energy became stable after a period of time. This was probably the result of the continuous dissipation of the energy, which lead to further developing of the fractures in the anchorage body and the shearing deformation along the sliding plane [42].

To monitor the degree of damage to the anchorage body, the total fracture length as well as the shear and tensile fracture lengths during uniaxial compression were measured. The degree of damage $(D)$ can be calculated as follows [36]:

$$
D=\frac{L_{S}+L_{T}}{L_{C}} \times 100 \%,
$$

where $L_{C}$ is the total fracture length, and $L_{S}$ and $L_{T}$ are the total shear and tensile fracture lengths, respectively.

Then, analysis was conducted on Figure 4 along the horizontal direction. The evolution characters of the stress, fracture, and energy in the anchorage body under different simulation schemes were compared and analyzed. Table 6 shows the specific data comparison of the stress and fractures in the anchorage body. The variation rate in the table was obtained by comparing with the data in Group 1.

With regard to the aspect of stress, the pretensioned rock bolts not only improve the elastic modulus of the anchorage body to improve its peak strength but also improve the postpeak character of the anchorage body (Figures 4(a)-4(c)). Then, the decreasing of the anchorage body strength can be reduced. The peak strength of the anchorage body with high pretensioned rock bolts installed reached 5.8 $\mathrm{MPa}$, improving by $13.7 \%$ compared with the coal mass that was not installed with the rock bolts. When there was no rock bolt installed, after the coal mass reached the peak, the stress curve decreased rapidly, with the strength decreasing from $5.1 \mathrm{MPa}$ to $2.3 \mathrm{MPa}$ (Figure 4(a)). After the pretensioned rock bolts were installed, the post-peak stresses were all above $4 \mathrm{MPa}$.

With regard to the aspect of fracture and damage, pretensioned rock bolts can effectively decrease the whole extent of damage of the anchorage body. After the low pretensioned rock bolts and high pretensioned rock bolts were installed, the whole extent of damage of the anchorage body decreased by $8.6 \%$ and $16.6 \%$. Besides, the quantity of the shearing fractures, the quantity of tensile fractures, and the tensile damaging extent showed a tendency to decrease. However, when the low pretensioned rock bolts were installed, the fracture evolution situation was different from the other two groups. Compared with the coal body without the rock bolts, the damage starting point of the anchorage body with low pretension bolts has not changed, and the tensile cracks and tensile damage increase rapidly and greatly between the strain of $0.5 \%-0.6 \%$. Moreover, the ultimate tensile fractures and the extent of tensile damage were higher compared with the coal mass that was not installed with the rock bolts (Figures 4(d) and 4(e)). The increasing rate reached $25.8 \%$ and $34 \%$, respectively. This was probably because the pretension applied on the rock bolt was relatively low. At the initial loading stage, the active reinforcing effect of the rock bolts was not apparent. Therefore, at the initial loading stage, the microfailure of the anchorage body occurred (with the strain ranging between $0.5 \%$ and $0.6 \%$ ). Furthermore, tensile failure occurred. This led to an increase in the ultimate fractures and the extent of tensile damage. When the strain was $0.6 \%$, the rock bolts started developing the active reinforcement effect. The tensile fractures became stable when the strain ranged from $0.6 \%$ to $0.76 \%$ (the corresponding strain for the peak strength). Based on the above analysis, the low pretensioned rock bolts cannot develop the active reinforcement effect at the initial reinforcing stage, which leads to an increase of tensile damage of the anchor body.

For energy, when plotting Figures 4(g)-4(i), energy dissipated by acoustic emission was plotted individually. The tendency of the acoustic emission energy curve was basically consistent with the tendency of the acoustic emission count curve. This was the important appearance of the anchorage body failure [31]. Figure 5 shows the specific data of each energy component after the simulation was finished. From the development tendency of the elastic strain energy curve, it can be seen that the whole process of the anchorage body failure was composed of energy charging and releasing. Therefore, the fracture initiating stage (Phase I) and the rapid developing stage of fractures (Phase II) were combined and called as the energy charging stage. The post-peak stage (Phase III) was called as the energy releasing stage. After the rock bolts were installed in coal strata, with the increasing of the pretension, the peak energy in the energy charging stage increased and the position of peak energy moved behind. Furthermore, under the situation of equal strain, the residual elastic strain energy is increased. At the peak position of the elastic strain energy, it entered the energy-releasing stage and massive energy was released. Energy was mainly dissipated through the developing of fractures and friction. Then, the energy was dissipated through the plastic applied work of the anchorage body. The dissipated energy by acoustic emission was minimal. The acoustic emission energy in three groups accounted for $5.7 \%, 14.4 \%$, and $16.9 \%$ of the released energy in each group. With an increase in the pretension, the dissipated energy through the fracture developing, friction, and the plastic applied work of the anchorage body showed a decreasing tendency. The acoustic emission energy and the residual elastic strain energy increased (Figure 5). This was mainly because when the rock bolt developed an active 


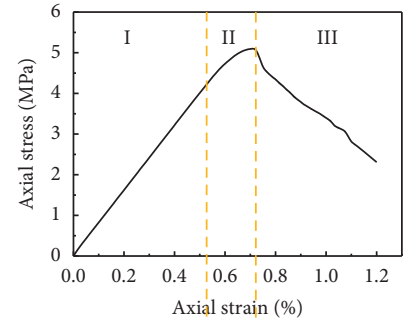

(a)

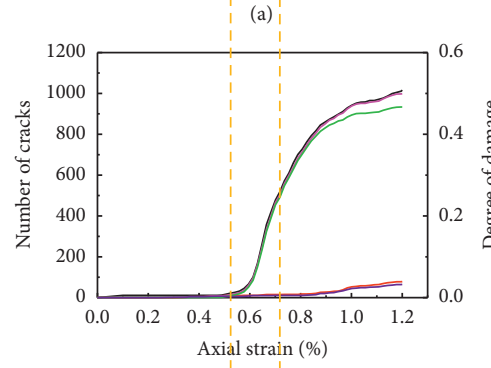

(d) ।

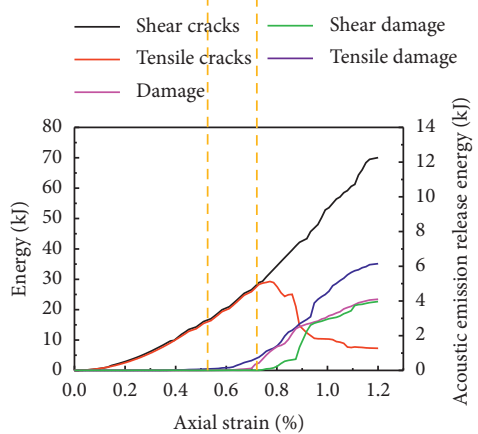

(g)

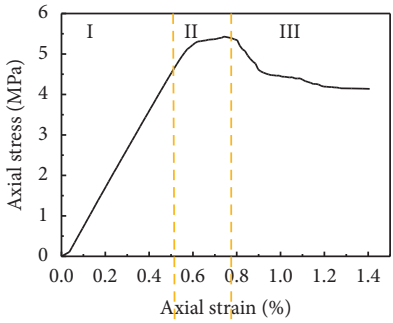

(b)

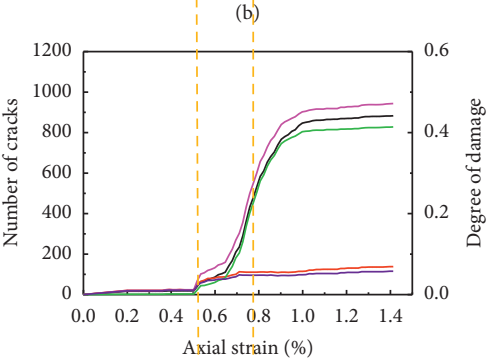

(e)

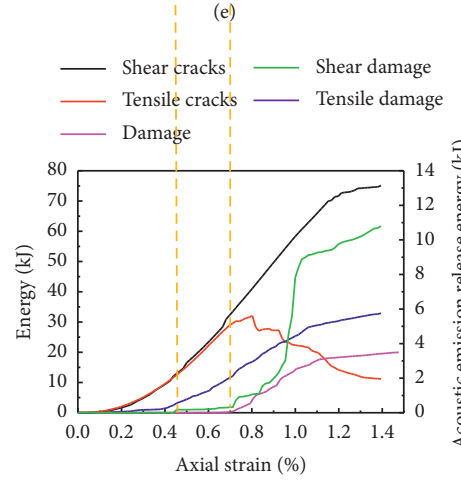

(h)

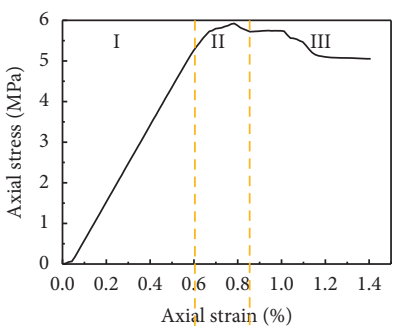

(c)

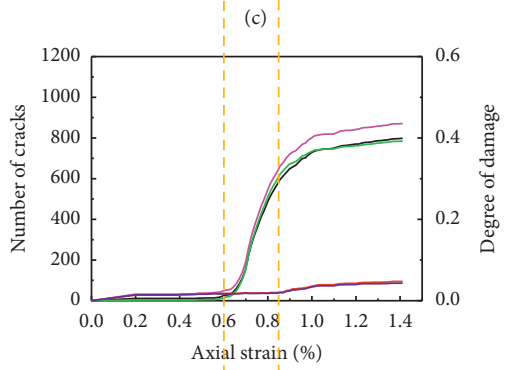

(f)

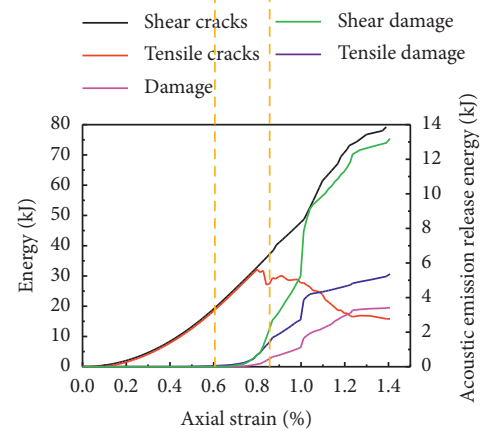

(i)

$$
\begin{array}{ccccc}
-\mathrm{W}^{\mathrm{W}} & -\mathrm{W}_{\mathrm{p}} & -\mathrm{W} & -\mathrm{W}_{\mathrm{p}} & \mathrm{W}_{\mathrm{w}} \\
\mathrm{U}^{\mathrm{e}} & -\mathrm{U}^{\mathrm{r}} & -\mathrm{U}^{\mathrm{e}} & -\mathrm{U}^{\mathrm{r}} & -\mathrm{U}^{\mathrm{e}}-\mathrm{U}^{\mathrm{r}} \\
\mathrm{W}_{\mathrm{f}} & & -\mathrm{W}_{\mathrm{f}} & -\mathrm{W}_{\mathrm{f}}
\end{array}
$$

\begin{tabular}{|c|c|c|c|c|}
\hline & Group 1 & Group 2 & Group 3 & Rate of change \\
\hline Peak strength & $5.1 \mathrm{MPa}$ & $5.4 \mathrm{MPa}$ & $5.8 \mathrm{MPa}$ & $\begin{array}{c}5.9 \% \\
13.7 \%\end{array}$ \\
\hline Quantity of the shearing fractures & 1068 & 887 & 800 & $\begin{array}{l}-16.9 \% \\
-25.1 \%\end{array}$ \\
\hline Quantity of tensile fractures & 116 & 146 & 95 & $\begin{array}{c}25.8 \% \\
-18.1 \% \\
\end{array}$ \\
\hline Total damaging extent & $52.4 \%$ & $47.9 \%$ & $43.7 \%$ & $\begin{array}{c}-8.6 \% \\
-16.6 \% \\
\end{array}$ \\
\hline Shearing damaging extent & $47.7 \%$ & $41.6 \%$ & $39.4 \%$ & $\begin{array}{l}-12.8 \% \\
-17.4 \%\end{array}$ \\
\hline Tensile damaging extent & $4.7 \%$ & $6.3 \%$ & $4.3 \%$ & $\begin{array}{l}34.0 \% \\
-8.5 \%\end{array}$ \\
\hline
\end{tabular}

FIGURE 4: Strength, fracture, and energy evolution of the anchorage body under uniaxial compression: (a) stress-strain curve (no rock bolt); (b) stress-strain curve (low pretensioned rock bolt); (c) stress-strain curve (high pretensioned rock bolt); (d) crack and damage curve (no rock bolt); (e) crack and damage curve (low pretensioned rock bolt); (f) crack and damage curve (high pretensioned rock bolt); (g) energy curve (no rock bolt); (h) energy curve (low pretensioned rock bolt); and (i) energy curve (high pretensioned rock bolt).

TABLE 6: Comparison of the stress and fractures in the anchorage body. 


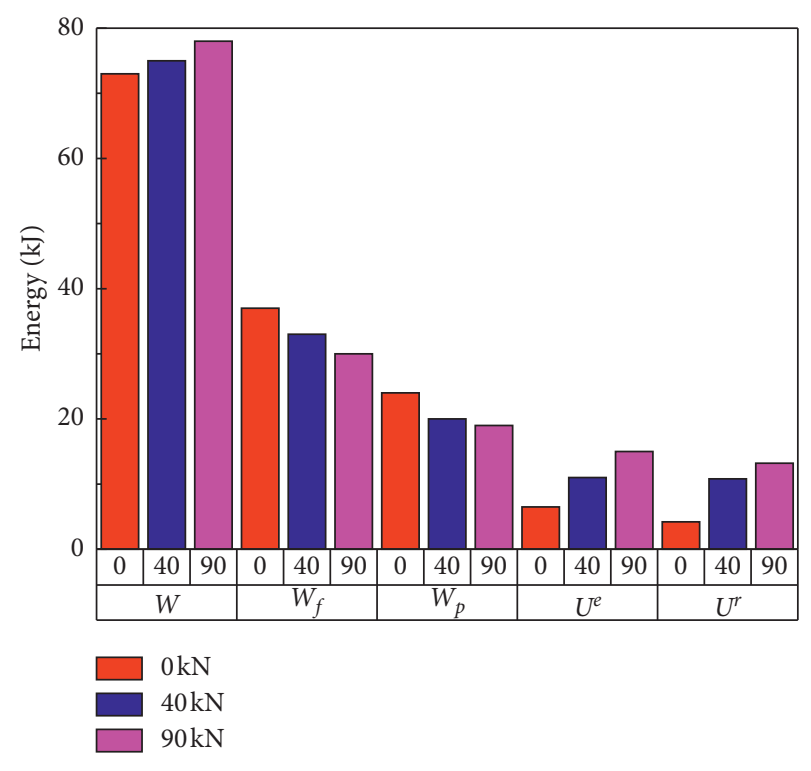

Figure 5: Data of each energy component.

reinforcing effect, it changed the physical and mechanical characters of the anchorage body. This improved the parameters such as the elastic modulus of the anchorage body. Also, this improved the ability of the anchorage body in resisting the developing of fractures and plastic deformation. Under the low pretensioned situation, in the energy charging stage, fracture developing and energy dissipating via friction occurred (Figure 4(h)). This was because in the initial reinforcement stage, the rock bolt reinforcement effect was poor. This led to the initiating and developing of tensile fractures. This was consistent with the fracture evolution curve (Figure 4(e)). Improving the rock bolt pretension can effectively improve this situation (Figure 4(i)). At the initial reinforcement stage, it developed the active reinforcement effect, ensuring the stability of the anchorage body.

\subsection{Strengthening of the High-Performance Anchorage Body} Strength. The rock bolt surrounding rock mass strength strengthening theory assumed that installing the high pretensioned rock bolts can effectively improve the mechanical parameters of the anchorage body. Also, the strength of the anchorage body can be improved. The plastic area, radius of the fractured zone, and the surface displacement can effectively be reduced. The stability of the surrounding rock mass can be maintained $[1,43]$. Based on the deformational failure character of the anchorage body and the energy dissipating rule in section 4.2 , this section explained the strength strengthening theory from the perspective of energy. Figure 6 shows the comparison between the peak strength, residual elastic strain energy, and the damaging extent of the anchorage body with different pretension forces after the simulation was finished.

The residual strain energy was the residual energy in the anchorage body after the simulation was finished. Figure 6 shows that applying high pretension forces can improve the residual strain energy of the anchorage body. This was because installation of high pretensioned rock bolts improved the mechanical parameters of the anchorage body. Meanwhile, the development of the fractures in the anchorage body was restricted. Then, the energy was dissipated by using two main approaches: fracture developing friction and plastic deformation. The residual strain energy had a positive relationship with the peak strength and a negative relationship with the damaging degree. Therefore, it can be assumed that the highperformance anchorage body constructed with high pretension has a high strength anchorage body with a low extent of damage. This was consistent with the rock bolt surrounding the rock mass strength strengthening theory. Therefore, constructing the high-performance anchorage body can effectively reduce the surface displacement of the surrounding rock masses.

\section{In Situ Tests and Observations}

5.1. Profile of Tensile Rock Bolts. Our research group developed a new rock bolt locking instrument, which changed the traditional rock bolt locking method. This solved the problem of low transferring efficiency in the torque and pretension, which occurred in the traditional torqued pretensioned rock bolts in essence. This effectively improved the rock bolt pretension and fully developed the active reinforcement effect of the rock bolts. The rock bolt locking instrument was composed of barrel and wedge. The barrel and wedge was a circular structure. At the middle of it, there was a cone hole. As for the clamping, there were multiple pieces. Its external surface radian dimension was matched with the cone hole. Meanwhile, its internal surface radian dimension was matched with the outside diameter of the rock bolts. The clamping was installed between the internal surface of the anchoring ring cone hole and the rock bolt (Figures 7(a) and 7(b)). A specially manufactured hydraulic jack was used to apply pretension. It can apply a pretension force of $90 \mathrm{kN}$ on threaded rock bolts (HRB 335) with a diameter of $22 \mathrm{~mm}$ without damaging, as shown in Figure 7 (d). It reached about $70 \%$ of the yielding capacity.

5.2. In Situ Observations. To verify the accuracy of the numerical simulation, experiments were conducted in the field. The location of the experiment was the transport roadway of the working face 6208 in the Wangzhuang Coal Mine in the city of Changzhi, Shanxi Province, China. The Working face 6208 was located in the coal seam 3\#, with an average thickness of $6.9 \mathrm{~m}$. The transport roadway of 6208 was tunneled along the gob. The excavation was conducted along the floor. Two sides of the roadway and the immediate roof were coal (Figure 8(a)). The head entry of the working face 6208 was excavated along the floor with a cross section of $5.0 \mathrm{~m}$ (in width) $\times 3.2 \mathrm{~m}$ (in height), as shown in Figure 8(b). In the working face 6208, the traditional torqued HRB 335 threaded rock bolts were used to perform the roadway reinforcement. The rock bolt diameter was $22 \mathrm{~mm}$ and the length was $2400 \mathrm{~mm}$, with $300 \mathrm{Nm}$ applied to provide the pretension. During the excavation period, the serious problem of surrounding the 


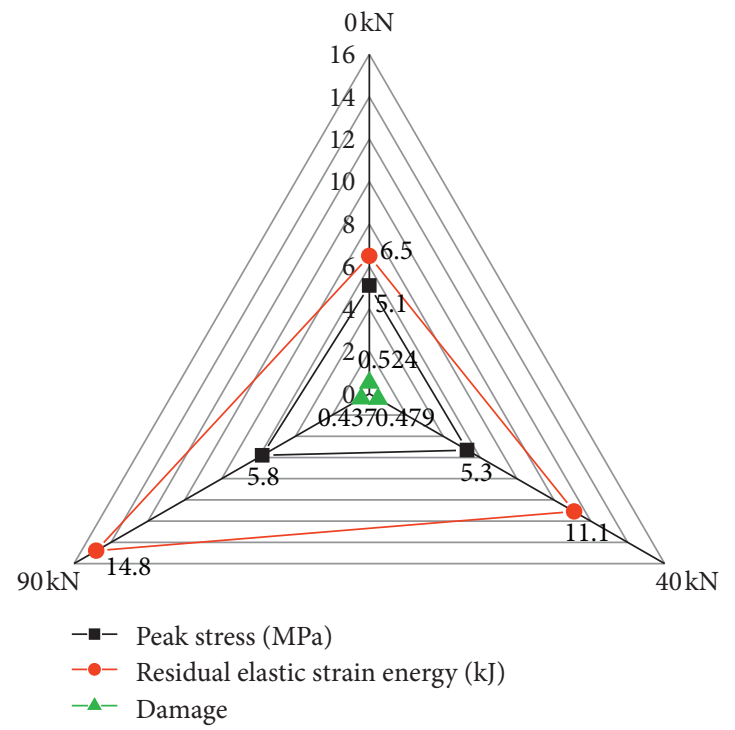

FIGURE 6: Comparison of peak strength, residual elastic strain energy, and damaging extent of anchorage body under different pretensions after the simulation was finished.

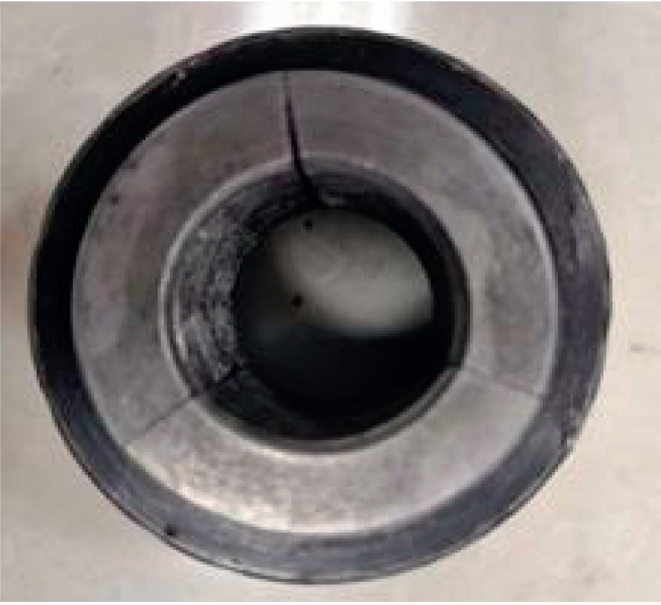

(a)

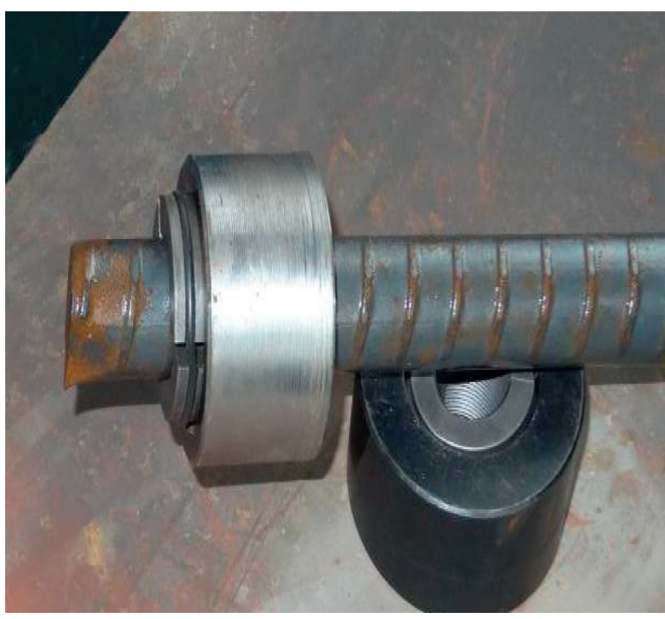

(c)

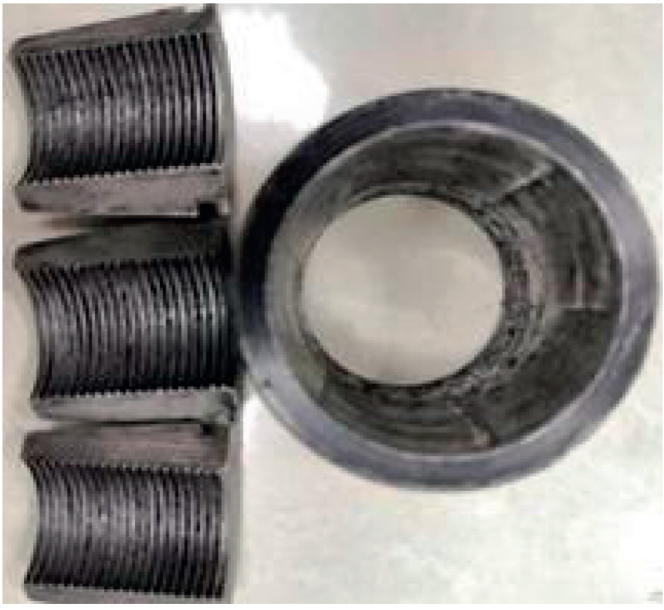

(b)

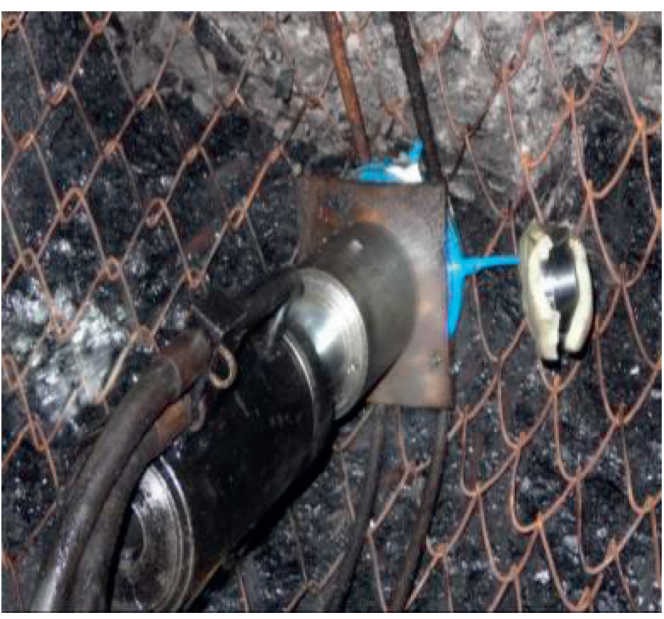

(d)

FIgURE 7: The anchoring system components: (a) barrel and wedge; (b) separated barrel and wedge; (c) barrel and wedge installed in the rock bolt; (d) barrel and wedge installation. 


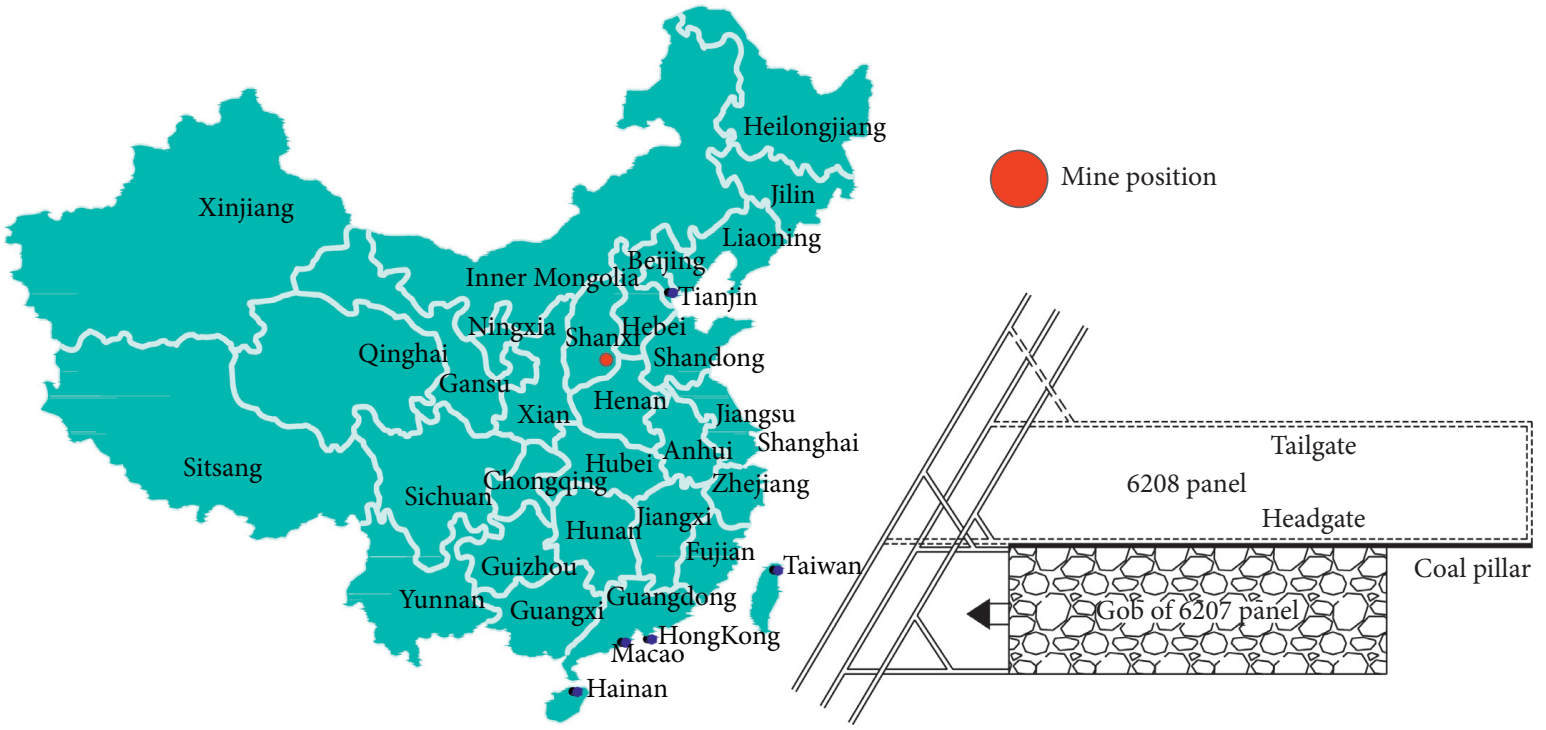

(a)

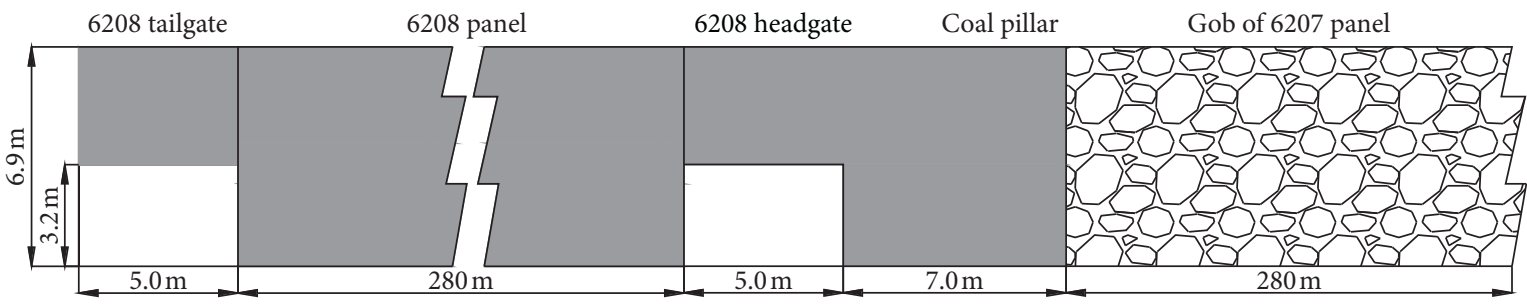

(b)

Figure 8: The panel introduction of sampling site: (a) mine position and plan view and (b) section view.

rock mass deformation at two sides of the roadway occurred, as shown in Figure 9. In this roadway, a length of $200 \mathrm{~m}$ was selected as the test section. Tensile rock bolts were installed. The rock bolt locking instrument was matched with the particularly manufactured hydraulic Jack to apply pretension on the HRB 335 threaded rock bolts with a diameter of $22 \mathrm{~mm}$. In the test, a pretension of $90 \mathrm{kN}$ was applied without damaging the rock bolt. In the torqued rock bolt section and the tensile rock bolt section, the surface displacement observation stations were installed to monitor the convergence of the two sides of the roadway during the tunneling period. Figure 10 shows the convergence of the two sides of the roadway in the torqued rock bolt test section and the tensile rock bolt test section during the tunneling period. With the tunneling face advancing, the deformation of the roadway surrounding the rock masses gradually increased. After the distance to the tunneling face was $100 \mathrm{~m}$, the convergence of the two sides of the roadway became stable. The maximum convergence of the two sides of the roadway for the torqued rock bolt test section was $527 \mathrm{~mm}$. As for the tensile rock bolt test section, the maximum convergence of the two sides of the roadway was $210 \mathrm{~mm}$. The maximum convergence of the two sides of the roadway was reduced by $60 \%$. Therefore, the tensile anchorage body constructed with tensile rock bolts can effectively reduce the 

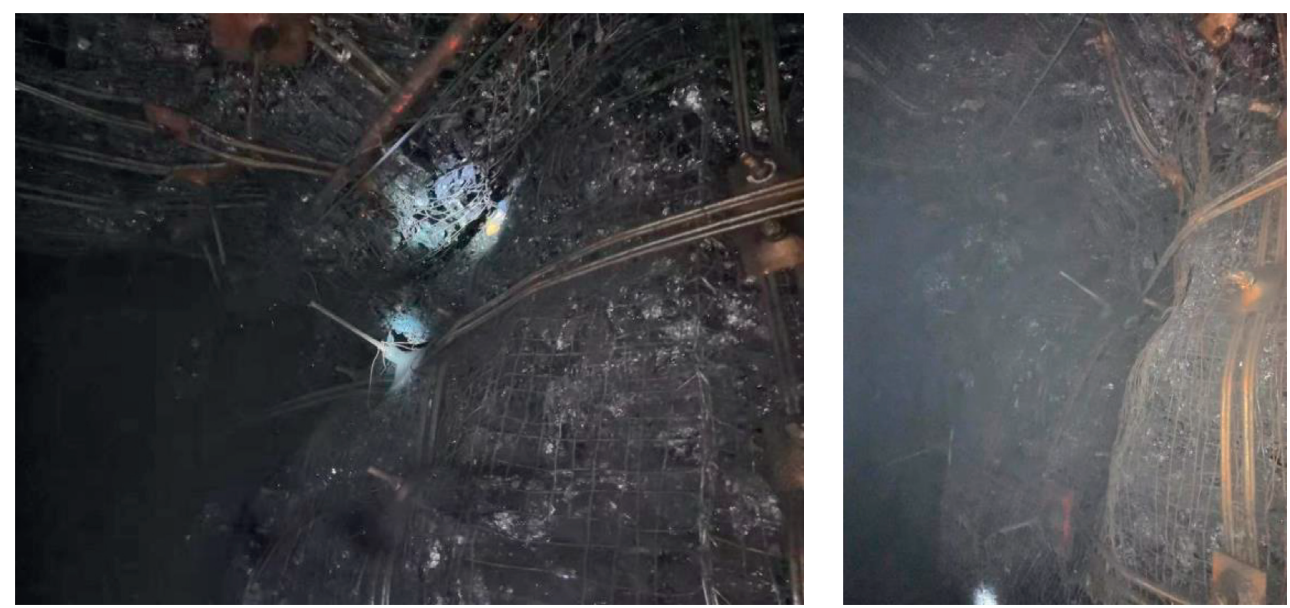

FIgURE 9: Deformation of the roadway surrounding the rock masses.

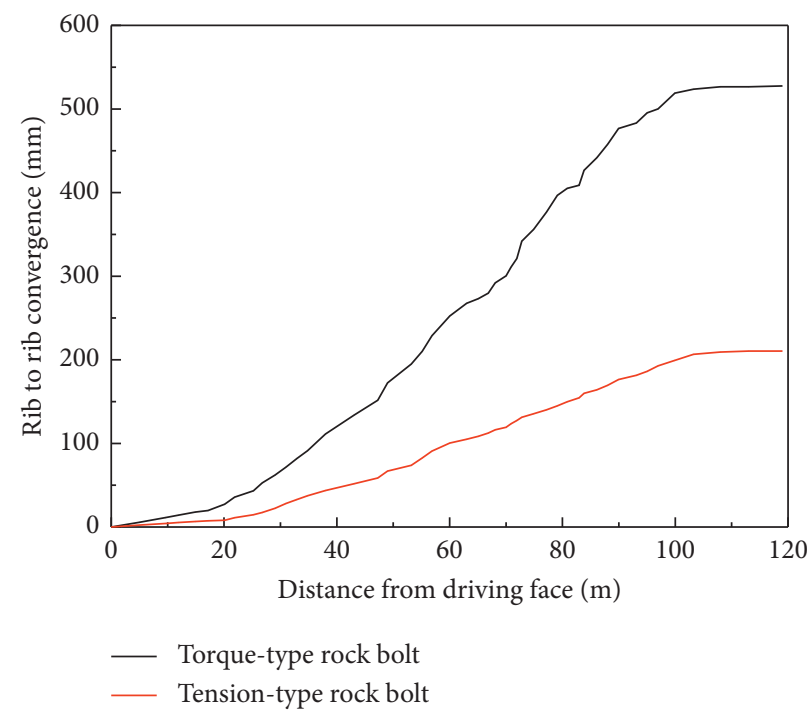

FIgURE 10: Convergence of head entry of the working face 6208 during tunneling.

deformation of the rock masses surrounding the roadway. Furthermore, the roadway surrounding the rock masses can be guaranteed to be stable.

\section{Conclusions}

In this study, the UDEC Trigon method was used to study the influence of pretension on the anchorage body strength and energy. The anchorage body model was composed of triangle deformable blocks. According to the standard calibration procedures, rigid calibration and validation were conducted on the input character of the anchorage body and the rock bolts. Then, through the UCS test, the anchorage body, and the influence of pretension force was studied. The following conclusions were acquired:

(1) High pretension rock bolts can reduce the extent of fractures in the anchorage body, especially the tensile fractures. The damage extent of the anchorage body was reduced, with a reduction of $16.6 \%$ with $90 \mathrm{kN}$.
Meanwhile, the anchorage body strength can be improved by $13.7 \%$, which effectively improved the stability of the anchorage body.

(2) According to the fracture development and energy dissipation character, the whole failure process of the anchorage body was composed of three stages: fracture initiating stage (Phase I), rapid developing stage of fractures (Phase II) and the post-peak stage (Phase III). The externally applied work was stored in the internal area of the anchorage body in the form of the elastic strain energy. Energy was dissipated through three approaches: fracture friction, plastic deformation, and acoustic emission. At the initial reinforcing period, the active reinforcement effect of the low pretensioned rock bolts was not apparent. At the initial reinforcement period, tensile fractures occurred. The energy was dissipated through applying work via fracture friction. With the increasing pre-tension, rock bolts can restrict the fracture 
friction and plastic deformation. This means that more elastic strain energy was stored in the anchorage body, forming the high-performance anchorage body.

(3) In the transport roadway of the Working face 6208 in the Wangzhuang Coal Mine in the city of Changzhi, Shanxi Province, China, an in situ experiment was conducted. The monitoring data showed that for the torqued rock bolt section, the maximum convergence of the two sides of the roadway was $527 \mathrm{~mm}$. As for tensile rock bolts, the maximum convergence of the two sides of the roadway was $210 \mathrm{~mm}$. The maximum convergence of the two sides of the roadway was reduced by $60 \%$. Therefore, through constructing high-performance anchorage body, the surface displacement of the surrounding rock mass can be effectively reduced.

\section{Data Availability}

The data used to support the findings of this study are available from the corresponding author upon request.

\section{Conflicts of Interest}

The authors declare that they have no conflicts of interest regarding the publication of this paper.

\section{Acknowledgments}

The authors are grateful for the support from the Fundamental Research Funds for the Central Universities (2018ZDPY02).

\section{References}

[1] H. Wu, X. K. Wang, W. Wang et al., "Deformation characteristics and mechanism of deep subsize coal pillar of the tilted stratum," Energy Science and Engineering, vol. 8, no. 2, pp. 544-561, 2020.

[2] C. J. Hou, X. Y. Wang, J. B. Bai et al., "Basic theory and technology study of stability control for surrounding rock in deep roadway," Journal of China University of Mining and Technology, vol. 50, no. 1, pp. 1-10, 2021.

[3] H. Jing, J. Wu, Q. Y. Qian, and K. Wang, "Deformation and failure characteristics of anchorage structure of surrounding rock in deep roadway," International Journal of Mining Science and Technology, vol. 30, no. 5, pp. 593-604, 2020.

[4] J. B. Yin and C. J. Hou, "Control principle of surrounding rocks in deep roadway and its application," Journal of China University of Mining and Technology, vol. 35, no. 2, pp. 145-148, 2006.

[5] A. Mirzaghorbanali, H. Rasekh, N. Aziz, G. Yang, S. Khaleghparast, and J. Nemcik, "Shear strength properties of cable bolts using a new double shear instrument, experimental study, and numerical simulation," Tunnelling and Underground Space Technology, vol. 70, pp. 240-253, 2017.

[6] Z. Wen, E. Xing, S. Shi, and Y. Jiang, "Overlying strata structural modeling and support applicability analysis for large mining-height stopes," Journal of Loss Prevention in the Process Industries, vol. 57, pp. 94-100, 2019.
[7] J. P. Zuo, J. H. Wen, Y. D. Li et al., "Investigation on the interaction mechanism and failure behavior between bolt and rock-like mass," Tunnelling and Underground Space Technology, vol. 93, Article ID 103070, 2019.

[8] J. K. Jiao, Burst failure mechanism and control technology of roadway anchorage bearing structure under dynamic load disturbance, Ph.D. thesis, China Coal Research Institute, Beijing, China, 2018.

[9] Z. Z. Zhang, M. Deng, X. Y. Wang et al., "Field and numerical investigations on the lower coal seam entry failure analysis under the remnant pillar," Engineering Failure Analysis, vol. 115, 2020.

[10] Z. Z. Zhang, M. Deng, J. B. Bai et al., "Stability control of gobside entry retained under the gob with close distance coal seams," International Journal of Mining Science and Technology, 2020.

[11] C. A. You, Theory and application study on stress-transfer mechanism of anchoring system, Ph.D. thesis, Shandong University of Science and Technology, Qingdao, China, 2004.

[12] H. P. Kang, T. M. Jiang, and F. Q. Gao, "Effect of pretension stress to rock bolting," Journal of China Coal Society, vol. 32, no. 7, pp. 680-685, 2007.

[13] K. Zhang, G. Zhang, R. Hou, Y. Wu, and H. Zhou, "Stress evolution in roadway rock bolts during mining in a fully mechanized longwall face, and an evaluation of rock bolt support design," Rock Mechanics and Rock Engineering, vol. 48, no. 1, pp. 333-344, 2015.

[14] S. J. Wei and P. F. Gou, "Analogy simulation test on strengthening effect for pretention of bolts on anchorage body," Journal of China Coal Society, vol. 37, no. 12, pp. 1987-1993, 2012.

[15] Q. Wang, Q. Qin, B. Jiang, H. C. Yu, R. Pan, and S. C. Li, "Study and engineering application on the bolt-grouting reinforcement effect in underground engineering with fractured surrounding rock," Tunnelling and Underground Space Technology, vol. 84, pp. 237-247, 2019.

[16] Y. Z. Wu, J. Y. Chen, J. K. Jiao et al., "Damage and failure mechanism of anchored surrounding rock with impact loading," Journal of China Coal Society, vol. 43, no. 9, pp. 2390-2397, 2018.

[17] Q. Wang, R. Pan, S. C. Li et al., "The control effect of surrounding rock with different combinations of the bolt anchoring lengths and pre-tightening forces in underground engineering," Environmental Earth Sciences, vol. 77, no. 13, pp. 501-514, 2018.

[18] G. Liu, J. K. Long, H. D. Cai et al., "Design method of synergetic support for coal roadway," Procedia Earth and Planetary Science, vol. 1, no. 1, pp. 524-529, 2009.

[19] H. P. Xie, Y. Ju, and L. Y. Li, "Criteria for strength and structural failure of rocks," Chinese Journal of Mechanical Engineering, vol. 24, no. 17, pp. 3003-3010, 2005.

[20] H. P. Xie, Y. Ju, L. Y. Li et al., "Energy mechanism of deformation and failure of rock masses based on energy dissipation and energy release principles," Chinese Journal of Mechanical Engineering, vol. 27, no. 9, pp. 1729-1938, 2008.

[21] Y. Zhang, X.-T. Feng, X. Zhang, Z. Wang, M. Sharifzadeh, and C. Yang, "A novel application of strain energy for fracturing process analysis of hard rock under true triaxial compression," Rock Mechanics and Rock Engineering, vol. 52, no. 11, pp. 4257-4272, 2019.

[22] V. P. Efimov, "Estimate of initial energy of rock failure activation by measuring rock resistance," Journal of Mining Science, vol. 40, no. 5, pp. 503-507, 2004. 
[23] J. A. Sanchidrián, P. Segarra, and L. M. López, "Energy components in rock blasting," International Journal of Rock Mechanics and Mining Sciences, vol. 44, no. 1, pp. 130-147, 2007.

[24] R. Peng, Y. Ju, J. G. Wang, H. Xie, F. Gao, and L. Mao, “Energy dissipation and release during coal failure under conventional triaxial compression," Rock Mechanics and Rock Engineering, vol. 48, no. 2, pp. 509-526, 2015.

[25] F.-Q. Gong, S. Luo, and J.-Y. Yan, "Energy storage and dissipation evolution process and characteristics of marble in three tension-type failure tests," Rock Mechanics and Rock Engineering, vol. 51, no. 11, pp. 3613-3624, 2018.

[26] Q. Meng, M. Zhang, L. Han, H. Pu, and T. Nie, "Effects of acoustic emission and energy evolution of rock specimens under the uniaxial cyclic loading and unloading compression," Rock Mechanics and Rock Engineering, vol. 49, no. 10, pp. 3873-3886, 2016.

[27] X. Dong, A. Karrech, H. Basarir, M. Elchalakani, and A. Seibi, "Energy dissipation and storage in underground mining operations," Rock Mechanics and Rock Engineering, vol. 52, no. 1, pp. 229-245, 2019.

[28] B. Wu, X. Wang, J. Bai, W. Wu, X. Zhu, and G. Li, "Study on crack evolution mechanism of roadside backfill body in gobside entry retaining based on UDEC Trigon model," Rock Mechanics and Rock Engineering, vol. 52, no. 9, pp. 33853399, 2019.

[29] Q. H. Wu, L. Weng, Y. L. Zhao et al., "Deformation and cracking characteristics of ring-shaped granite with inclusion under diametrical compression," Arabian Journal of Geosciences, vol. 13, pp. 681-692, 2020.

[30] N. G. W. Cook, E. Hoek, and J. P. G. Pretorius, "Rock mechanics applied to the study of rockbursts," Journal of the South African Institute of Mining and Metallurgy, vol. 66, no. 10, pp. 435-528, 1966.

[31] J. B. Walsh, "Energy changes due to mining," International Journal of Rock Mechanics and Mining Sciences \& Geomechanics Abstracts, vol. 14, no. 1, pp. 25-33, 1977.

[32] M. D. G. Salamon, "Energy considerations in rock mechanics: fundamental results," Journal of the South African Institute of Mining and Metallurgy, vol. 84, no. 8, pp. 233-246, 1984.

[33] J. A. L. Napier, "Energy changes in a rockmass containing multiple discontinuities," Journal of the Southern African Institute of Mining and Metallurgy, vol. 91, no. 5, pp. 145-157, 1991.

[34] V. Onur, C. G. Zhang, C. Ismet et al., "Numerical modelling of strength and energy release characteristics of pillar-scale coal mass," Journal of Rock Mechanics and Geotechnical Engineering, vol. 11, pp. 935-943, 2019.

[35] Itasca Consulting Group Inc., UDEC (Universal Distinct Element Code), Itasca Consulting Group Inc., Minneapolis, Min, USA, Version 6.0, 2014.

[36] F. Gao, D. Stead, and J. Coggan, "Evaluation of coal longwall caving characteristics using an innovative udec trigon approach," Computers and Geotechnics, vol. 55, no. 55, pp. $448-460,2014$.

[37] L. Zhang and H. H. Einstein, "Using RQD to estimate the deformation modulus of rock masses," International Journal of Rock Mechanics and Mining Sciences, vol. 41, no. 2, pp. 337-341, 2004.

[38] M. Singh and K. Seshagiri Rao, "Empirical methods to estimate the strength of jointed rock masses," Engineering Geology, vol. 77, no. 1-2, pp. 127-137, 2005.
[39] B. W. Wu, X. Y. Wang, J. B. Bai et al., "An investigation on the effect of high energy storage anchor on surrounding rock conditions," Royal Society Open Science, vol. 7, no. 10, 2020.

[40] R. K. Zipf, "Numerical modeling procedures for practical coal mine design," in Proceedings of the 41st US Rock Mechanics Symposium, no. 1-11Golden, CO, USA, June 2006.

[41] H. Kang, Y. Wu, F. Gao et al., "Mechanical performances and stress states of rock bolts under varying loading conditions," Tunnelling and Underground Space Technology, vol. 52, pp. 138-146, 2016.

[42] Z. Z. Zhang, M. Deng, J. B. Bai et al., "Strain energy evolution and conversion under triaxial unloading confining pressure tests due to gob-side entry retained," International Journal of Rock Mechanics and Mining Science, vol. 126, 2020.

[43] C. J. Hou and P. F. Gou, "Study on the strengthening mechanism of surrounding rock strength with bolting support," Chinese Journal of Mechanical Engineering, vol. 19, no. 3, pp. 342-345, 2000. 